\title{
Pelatihan Penulisan Jurnalistik dan Naskah Kehumasan bagi Siswa- Siswi SMA Muhammadiyah 3 Jakarta Selatan
}

\author{
Novi Andayani Praptiningsih', Syaiful Rohim ${ }^{1}$ \\ ${ }^{1}$ Universitas Muhammadiyah Prof. DR. HAMKA, Jl. Tanah Merdeka, Jakarta Timur, Indonesia \\ Email: noviap1711@gmail.com
}

\begin{abstract}
Abstrak
Pengabdian dan Pemberdayaan pada Masyarakat berupa pelatihan ketrampilan jurnalistik dan penulisan naskah kehumasan bagi siswa siswi SMA Muhammadiyah 3, berlokasi di Jalan Limau, Kebayoran Baru, Jakarta Selatan. Alasan memilih sekolah ini adalah sebagai bentuk pengabdian pada kader Muhammadiyah, terutama generasi muda, sehingga mampu menjadi manusia unggul yang mampu bersaing baik lingkup regional, nasional, maupunn internasional. Di samping itu, siswa-siswi SMA Muhammadiyah 3 Jakarta Selatan, yang berada di bawah payung besar lembaga Dakwah Muhammadiyah patut memperoleh ketrampilan jurnalistik dan penulisan naskah kehumasan secara benar dan efektif, sehingga pandai berargumentasi dan mampu mengaplikasikan tulisan naskah-naskah publikasi formal yang informatif dan menarik. Pelatihan yang bekerja sama dengan Majelis Pustaka dan Informasi (MPI) Pimpinan Wilayah Muhammadiyah DKI Jakarta ini, menekankan pada makna belajar (learning). Belajar adalah proses perubahan perilaku atau pribadi seseorang berdasarkan praktek atau pengalaman tertentu. Artinya setelah memiliki pengalaman mengikuti pelatihan jurnalistik dan penulisan naskah kehumasan diharapkan para peserta mendapat tambahan pengetahuan dan pengalaman yang dapat menunjang kegiatan dan kemampuannya dalam berorganisasi di sebuah lembaga. Dengan adanya pelatihan jurnalistik akan sangat membantu pelajar dalam mengasah kreatifitas dan bakat seseorang, khususnya dalam bidang tulis menulis. Dengan jurnalistik juga mampu membangun daya kritis nalar pelajar dalam membaca realitas kehidupan. Bidang Public Relations atau biasa disingkat dengan PR atau dapat juga dikatakan Hubungan Masyarakat atau Humas sebagai sebuah profesi semakin kuat berkembang. Individu bergantung kepada hubungan baik dengan kelompok-kelompok lainnya dan individu-individu yang memiliki berbagai pendapat, keputusan dan tindakan yang mempengaruhi vitalitas/daya dan kelangsungan hidup mereka. Upaya yang senantiasa diperjuangkan oleh seorang praktisi Public Relations adalah bagaimana dapat menginformasikan berbagai momen penting, khususnya yang berhubungan dengan terobosan dan perkembangan kekinian.
\end{abstract}

Kata kunci :ketrampilan, pelatihan, jurnalistik, naskah, kehumasan

\begin{abstract}
The form of Corporate Social Responsibility in terms of workshop who has the theme relating to journalism skills and public realtion proposal writing towards SMA Muhammadiyah 3, located in Jalan Limau, Kebayoran Baru, South Jakarta. The importance of choosing this school is as form of organizational responsibilty towards Muhammadiyah, especially young generation, in order to become a remarkable human being that can compete whether in regional, national, and of course international. Aside from that, the students of SMA Muhammadiyah 3, which is the part of da'wah institutional Muhammadiyah, should get this kind of benefit in order to learn journalism skills and public relation proposal writing in a correct way. The objectives are the students would be able to think and speak for their arguments towards a fact and have the ability to apply their writing skills in terms of scientific journal or popular article. This workshop is held together with Majelis Pustaka dan Informasi (MPI) Regional Leader of Muhammadiyah DKI Jakarta, emphasizing in the meaning of "learning" itself. Learning is a changing process of behaviors or personality of individuals based on practice or specific experiences. That means after participating this workshop, the participants are hoped to get new information, knowledge, and experiences in which could help them to get involved in organizational institution. This workshop is aimed to help the participants to explore their creativities and talent and also practice their writing skills. Journalism could also help the students to understand the way life works. PR or commonly is abbreviation for Public Relations could also known in our society called Humas. This profession nowadays is getting more developed. An individual is most likely depending on the relationship between the groups of people and others individuals who always share their opinion, decision, and action which affecting vitality/power and sustainability of their lives. The most common thing that a Public Relations do is to inform any important moment, especially dealing with innovation and information up to these days.
\end{abstract}


Keywords: skills, training, journalism, script, public relations

Format Sitasi: Praptiningsih, N.A. \& Rohim, S. (2018). Pelatihan Penulisan Jurnalistik dan Naskah Kehumasan Bagi Siswa-siswi SMA Muhammadiyah 3 Jakarta Selatan. Jurnal SOLMA, 07(1), 99-119.

Revisi: 28-01-2018; Diterima: 15-03-2018; Diterbitkan: 07-04-2018.

\section{PENDAHULUAN}

Pers adalah lembaga sosial dan wahana komunikasi massa yang melaksanakan kegiatan jurnalistik meliputi mencari, memperoleh, memiliki, menyimpan, mengolah dan menyampaikan informasi, baik dalam bentuk tulisan, suara, gambar, serta data dan grafik maupun dalam bentuk lainnya dengan menggunakan media cetak, media elektronik, serta media online. Peran pers sangat besar dalam realitas kehidupan, diantaranya adalah memberikan informasi sampai kepada masyarakat, baik tingkat atas, menengah, maupun tingkat bawah. Hal ini karena keberadaan pers di Indonesia sangat sangat terbuka dan dapat diterima masyarakat secara luas.

Kemerdekaan pers merupakan salah satu wujud kedaulatan rakyat dan menjadi unsur yang sangat penting untuk menciptakan kehidupan bermasyarakat, berbangsa dan bernegara yang demokratis, sehingga kemerdekaan mengeluarkan pikiran dan pendapat sebagaimana tercantum dalam Pasal 28 Undang-Undang Dasar 1945 harus dijamin.

Sebagaimana keberadaan pers dalam perspektif Undang-Undang, pers juga mempunyai peran dalam mencerdaskan anak bangsa, baik secara langsung maupun tidak langsung, yang bisa dimasukkan dalam bingkai pendidikan. Dalam dunia pendidikan, kecerdasan seseorang sangat menentukan keberhasilan dari sebuah proses pendidikan, yang mana orang yang cerdas akan mendapatkan prestasi yang memuaskan. Kecerdasan seseorang tidak bisa datang begitu saja tapi perlu dibangun melalui kebiasaan-kebiasaan yang mampu merangsang kecerdasan seseorang, salah satunya adalah baca tulis, yang dalam hal ini bisa dibangun melalui pelatihan jurnalistik.

Dengan adanya pelatihan jurnalistik akan sangat membantu pelajar dalam mengasah kreatifitas dan bakat seseorang, khususnya dalam bidang tulis menulis. Dengan jurnalistik juga mampu membangun daya kritis nalar pelajar dalam membaca realitas kehidupan. Bidang Public Relations atau biasa disingkat dengan PR atau dapat juga dikatakan Hubungan Masyarakat atau Humas telah mengalami pertubuhan yang luar biasa. PR/Humas sebagai sebuah profesi semakin kuat berkembang, karena adanya suatu masyarakat demokratis dimana orang-orang memiliki kebebasan untuk berdebat 
(berbicara) dan mengambil berbagai keputusan dalam suatu komunitas. Pribadi/Individu bergantung kepada hubungan baik dengan kelompok-kelompok lainnya dan individuindividu yang memiliki berbagai pendapat, keputusan dan tindakan yang mempengaruhi vitalitas/daya dan kelangsungan hidup mereka.

Kegiatan PR/Humas sebagai mediator yang menjembatani kepentingan organisasi/perusahaan dengan publiknya yang terkait dengan kegiatan PR itu sendiri. Berbagai aktivitas senantiasa menciptakan, menjaga dan meningkatkan citra yang positif.

F. Rachmadi dalam bukunya Public Relations dalam Teori dan Praktek menyebutkan bahwa masalah penting yang dihadapi oleh lembaga-lembaga seperti ekonomi, bisnis, sosial dan politik adalah masalah hubungan (relationship). Permasalahannya berkisar pada pertanyaan bagaimana membangun dan mengembangkan hubungan-hubungan yang baik antara lembaga-lembaga tersebut dengan masyarakat (publik) demi tercapainya tujuan organisasi/lembaga. Kegiatan PR/Humas sebagai mediator yang menjembatani kepentingan organisasi/perusahaan dengan publiknya yang terkait dengan kegiatan PR itu sendiri. Berbagai aktivitas senantiasa menciptakan, menjaga dan meningkatkan citra yang positif.

Public Relations (PR) atau Humas pada hakikatnya adalah kegiatan komunikasi, kendati berbeda dengan kegiatan komunikasi lainnya karena ciri hakiki dari komunikasi PR adalah two way communications (komunikasi dua arah/timbal balik). Arus komunikasi timbal balik ini yang harus dilakukan dalam kegiatan PR, sehingga terciptanya umpan balik yang merupakan prinsip pokok dalam PR (Rachmadi, 1994 :7).

Kegiatan Public Relations (Humas), merupakan kegiatan yang berkaitan dengan fungsi dan peranannya dalam kehumasan baik di dalam lembaga pemerintah, swasta, organisasi profit dan non profit tidak lepas dari etika kehumasan sebagai patokan atau pedoman atau rambu-rambu yang penting dan mendasar serta yang harus ditaati dan dipatuhi oleh setiap praktisi Public Relations (humas). Apa yang dimaksud Public Relations (humas), Maka dalam hal ini yang dimaksud dengan Humas (Public Relations) menurut Frank Jefkins adalah sesuatu yang merangkum keseluruhan komunikasi yang terencana baik kedalam maupun keluar antara suatu organisasi dengan semua khalayak dalam rangka mencapai tujuan-tujuan spesifik yang berlandaskan pada saling pengertian. PR atau Humas pada hakikatnya adalah kegiatan komunikasi, kendati agak lain dengan kegiatan komunikasi lainnya karena ciri hakiki dari komunikasi PR adalah two way 
communications (komunikasi dua arah/timbal balik). Arus komunikasi timbal balik ini yang harus dilakukan dalam kegiatan PR, sehingga terciptanya umpan balik yang merupakan prinsip pokok dalam PR (Rachmadi, 1994 :7).

Komunikasi dan manajemen menjadi dasar yang sangat fundamental dalam pekerjaan seorang Public Relations (Humas) dan supaya suasana komunikasi efektif dapat tercipta didalam suatu organisasi ada dengan syarat yang harus dipenuhi seorang Public Relations yaitu :

1. Komunikasi dan relasi.

2. Sifat yang rendah hati.

3. Cepat menyesuaikan diri.

4. Mampu menghadapi semua orang yang memiliki aneka ragam karakter dan latar belakang budaya dengan baik.

5. Mampu bekomunikasi dengan baik; menjelaskan dengan jernih, jelas, dan lugas secara lisan maupun tertulis juga secara visual.

6. Pandai mengorganisir segala sesuatu.

7. Memiliki integritas personal baik dalam profesi maupun kehidupan pribadi.

8. Punya imajinasi yang kuat dalam penyampaian pesan kepada stakeholder.

9. Serba tahu; memiliki akses yang tinggi terhadap informasi (membaca, membuka internet, berdiskusi dll).

Hal-hal yang sangat esensial dalam pekerjaan seorang Public Relations (humas) yaitu :

1. Komunikasi dan relasi. Menjadi rohnya Public Relations.

2. Goodwill ; itikad baik dalam berbisnis dalam melakukan kegiatan sehari-hari.

3. Good business is good service; pelayanan menjadi faktor penting dalam menentukan citra perusahaan.

4. Good business is good relations ; dimana prinsip komunikasi dua arah bersifat timbal balik.

5. Di era keterbukaan sekarang ini Humas mempunyai peran ynag penting dan strategis. Humas adalah kegiatan komunikasi dalam organisasi yang berlangsung dua arah dan timbal balik. Posisi Humas merupakan penunjang tercapainya tujuan yang ditetapkan oleh suatu manajemen organisasi. 
6. Sasaran Humas adalah publik internal dan eksternal, di mana secara operasional Humas bertugas membina hubungan harmonis antara organisasi dengan publiknya dan mencegah timbulnya rintangan psikologis yang mungkin terjadi di antara keduanya. Secara definitif, Humas adalah suatu fungsi manajemen yang bertujuan menjembatani antara organisasi dan stakeholder baik di luar maupun di dalam. Apa pun yang terjadi di organisasi, Humas harus tahu. Humas harus mengetahui segala kebijakan dari organisasi. Jadi Humas sebagai juru bicara pemerintah harus mengetahui segala kebijakan publik yang diambil itu dapat diimplementasikan dengan baik, sangat membutuhkan dukungan publik. Tapi bagaimana publik mau mendukung, kalau tidak mengetahui maksud kebijakan tersebut.

7. Di samping itu, sering ditemui masalah yaitu kebijakan publik yang diambil pejabat ditanggapi salah oleh masyarakat. Ini terjadi, karena kurangnya informasi yang diterima masyarakat terkait dengan maksud dan tujuan dari kebijakan tersebut. Untuk itu sangat diperlukan penyampai pesan yang baik, dan humas harus mampu memfasilitasinya.

8. Humas juga berperan menjembatani antara kepentingan pemerintah dan masyarakat daerah di satu pihak dengan pihak-pihak lain dalam meningkatkan kinerja pembangunan di masyarakat serta kegiatan pemerintahan. Jadi salahsatu peran Humas adalah membina hubungan yang harmonis dengan masyarakat dan membina martabat instansi dalam pandangan masyarakat, guna memperoleh pengertian, kepercayaan dan dukungan dari masyarakat.

9. Selain itu, seiring pelaksanaan otonomi daerah yang dititikberatkan pada pemberdayaan dan peran serta masyarakat, menjadikan peran aparatur Humas dan lembaga kehumasan pemerintah sebagai jembatan antara kepentingan pemerintah daerah dengan masyarakat.

Di dalam kelompok/organisasi itu selalu terdapat bentuk kepemimpinan yang merupakan masalah penting untuk kelangsungan hidup kelompok, yang terdiri dari pemimpin dan bawahan/karyawan. Di antara kedua belah pihak harus ada two-waycommunications atau komunikasi dua arah atau komunikasi timbal balik, untuk itu diperlukan adanya kerja sama yang diharapkan untuk mencapai cita-cita, baik cita-cita pribadi, maupun kelompok, untuk mencapai tujuan suatu organisasi. Hubungan yang terjadi merupakan suatu proses adanya suatu keinginan masing-masing individu, untuk 
memperoleh suatu hasil yang nyata dan dapat memberikan manfaat untuk kehidupan yang berkelanjutan, salah satunya adalah melalui ketrampilan penulisan naskah jurnalistik termasuk di dalamnya teknik menulis naskah humas (Public Relations Writing).

Teknik Penulisan Naskah Kehumasan (Public Relations Writing) adalah keterampilan menulis (writing skill) khas Humas/PR dalam menghasilkan naskah-naskah yang diperlukan untuk kepentingan pencitraan positif dan popularitas perusahaan/organisasi. Tipe-tipe penulisan atau naskah PR dapat dibagi menjadi dua bagian:

1. Berkaitan dengan Media Relations/Press Relations, seperti naskah press release (siaran pers), advertorial, dan press conference (press kit/media kit).

2. Berkaitan dengan Media Promosi, Informasi, dan Publikasi, seperti naskah untuk dipublikasikan di newsletter, in house magazine, naskah laporan tahunan (annual report), company profile, brosur (leaflet, pamflet, booklet), dan sebagainya.

Untuk menghasilkan naskah yang baik (good writing), Humas/PR harus memiliki keterampilan jurnalistik layaknya wartawan/reporter, seperti pemahaman tentang nilai berita (news values), bahasa jurnalistik (language of mass communications), kode etik jurnalistik, dan sebagainya. Demi kepentingan publikasi yang luas, Humas/PR membutuhkan peran media. Karena itu, diperlukan sebuah hubungan yang baik dengan kalangan pers/media massa (Press/Media Relations). Agar hubungan itu tercipta dengan baik, Humas perlu mengenali dunia pers dengan baik pula, seperti karakteristik wartawan, format media, cara kerja wartawan/media, dan sebagainya. Siaran Pers (Press Release, biasa disebut rilis saja) adalah naskah berita (data atau informasi tentang sebuah kegiatan pra ataupun pasca) yang disampaikan kepada wartawan atau kantor redaksi media untuk dipublikasikan di media tersebut. Dengan demikian, menulis siaran pers pada dasarnya sama dengan menulis berita seperti dilakukan para wartawan. Oleh karenanya, karakteristik dan struktur penulisan siaran pers sama dengan menulis berita.

Berdasarkan hal tersebut di atas, maka pelatihan untuk meningkatkan kepercayaan diri dan ketrampilan Penulisan Jurnalistik (baik mencari dan menyusun berita, maupun menulis naskah kehumasan) perlu dilakukan bagi siswa-siswi SMA Muhammadiyah 3 Kebayoran Baru, Jakarta Selatan. Sebagai kader Muhammadiyah diharapkan kelak mampu bersaing di kancah global, karena ketrampilan menulis karya jurnalistik, baik kemampuan 
menulis naskah/berita jurnalistik maupun kemampuan teknik menulis naskah-naskah kehumasan, publikasi dan komunikasi sudah dimiliki.

Lokasi Pengabdian pada Masyarakat adalah di SMA Muhammadiyah 3, Jalan Limau II, Kebayoran Baru, Jakarta Selatan. Alasan memilih lokasi ini adalah :

1. Sebagai bentuk pengabdian pada kader Muhammadiyah, terutama generasi muda, sehingga mampu menjadi manusia unggul yang mampu bersaing baik lingkup regional, nasional, maupun internasional.

2. Siswa-siswi SMA Muhammadiyah 3 yang berada di bawah payung besar lembaga Dakwah Muhammadiyah patut memperoleh ketrampilan komunikasi (menulis naskah jurnalistik dan naskah kehumasan) secara benar, sehingga pandai dan mampu mengaplikasikan tulisan naskah-naskah publikasi formal yang informatif dan menarik.

\section{MASALAH}

Sehubungan dengan paparan analisis situasi di atas maka dapat dirumuskan permasalahan sebagai berikut : "Bagaimana Pelaksanaan Pelatihan Penulisan Jurnalistik dan Naskah Kehumasan (PR Writing) bagi siswa-siswi SMA Muhammadiyah 3 Kebayoran Baru, Jakarta Selatan?"

Permasalahan tersebut mengingat saat ini opini publik banyak dibentuk oleh media massa. Pembentukan citra organisasi termasuk sekolah salah satunya tergantung pada branding sekolah serta pencitraan melalui penulisan naskah Public Relations. Dengan demikian siswa/i perlu dibekali menulis karya Jurnalistik dan PR agar mampu membentuk opini publik yang pada akhirnya memperoleh reputasi dan goodwill masyarakat.

Dari permasalahan tersebut di atas dapat diidentifikasi permasalahan mitra, sebagai berikut :

1. Bagaimana menginformasikan pentingnya meningkatkan kemampuan menulis naskah jurnalistik dan menyusun naskah kehumasan (PR Writing) ?

2. Bagaimana mengedukasi dalam meningkatkan kemampuan menulis naskah jurnalistik dan menyusun naskah kehumasan (PR Writing)?

3. Bagaimana teknik dan strategi dalam menulis naskah jurnalistik serta menyusun naskah kehumasan (PR Writing)?

\section{METODE}

Tujuan Kegiatan Pengabdian Kepada Masyarakat ini adalah untuk membantu secara langsung dan memberikan pembelajaran pada siswa-siswi SMA Muhammadiyah 3 doi: https://doi.org/10.29405/solma.v7i1.660 
Kebayoran Baru, Jakarta Selatan, bertema : "Pelatihan Jurnalistik dan Naskah Kehumasan (PR Writing) bagi siswa-siswi SMA Muhammadiyah 3 Kebayoran Baru, Jakarta Selatan”.

Tujuannya adalah :

1. Mengetahui pentingnya meningkatkan meningkatkan kemampuan menulis naskah jurnalistik dan menyusun naskah kehumasan ( $P R$ Writing).

2. Mengedukasi dan meningkatkan kemampuan meningkatkan kemampuan menulis naskah jurnalistik dan menyusun naskah kehumasan ( $P R$ Writing).

3. Mengaplikasikan teknik, strategi, dan taktik dalam meningkatkan kemampuan menulis naskah jurnalistik dan menyusun naskah kehumasan ( $P R$ Writing).

\section{PEMBAHASAN}

Teknik penulisan Jurnalistik tidak jauh berbeda dengan teknik penulisan naskah Kehumasan (Public Relations Writing), yakni memenuhi unsur 5W1H (What-Who-WhenWhere-When + How) yang seluruhnya harus berada dalam kapasitas piramida terbalik yang berisi : lead, isi berita/naskah, dan penutup.

Teknik penulisan Humas adalah keterampilan menulis (writing skill) khas Humas/PR dalam menghasilkan naskah-naskah yang diperlukan untuk kepentingan pencitraan positif dan popularitas perusahaan/organisasi. Tipe-tipe panulisan atau naskah PR dapat dibagi menjadi dua bagian:

1. Berkaitan dengan Media Relations/Press Relations, seperti naskah press release (siaran pers), advertorial, dan press conference (press kit/media kit).

2. Berkaitan dengan media promosi, informasi, dan komunikasi perusahaan/organisasi, seperti naskah untuk dipublikasikan di newsletter, in house magazine/Company Magazines, naskah laporan tahunan (annual report), company profile, leaflet, booklet, brosur, dan sebagainya.

Untuk menghasilkan naskah yang baik (good writing), Humas/PR harus memiliki keterampilan jurnalistik layaknya wartawan, seperti pemahaman tentang nilai berita (news values), bahasa jurnalistik (language of mass communications), kode etik jurnalistik, dan sebagainya.

Untuk kepentingan publikasi yang luas, Humas/PR membutuhkan peran media. Karena itu, diperlukan sebuah hubungan yang baik dengan kalangan pers/media massa (Press/Media Relations). Agar hubungan itu tercipta dengan baik, Humas perlu mengenali 
dunia pers dengan baik pula, seperti karakteristik wartawan, format media, cara kerja wartawan/media, dan sebagainya.

1. Siaran Pers

Siaran Pers (Press Release, biasa disebut rilis saja) adalah naskah berita (data atau informasi tentang sebuah kegiatan -pra ataupun pasca) yang disampaikan kepada wartawan atau kantor redaksi media untuk dipublikasikan di media tersebut. Dengan demikian, menulis siaran pers pada dasarnya sama dengan menulis berita seperti dilakukan para wartawan. Oleh karenanya, karakteristik dan struktur penulisan siaran pers sama dengan menulis berita.

Karakteristik siaran pers adalah memiliki "nilai berita" (news values), yakni aktual, faktual, penting, dan menarik. Struktur penulisannya pun sama dengan dengan penulisan berita, yakni terdiri dari head (Judul), dateline (baris tanggal), lead (teras berita), dan news body (tubuh atau isi berita). Berita sendiri artinya adalah laporan peristiwa atau peristiwa yang dilaporkan oleh media massa.

Kiat menulis siaran pers:

a. Tulis dengan gaya penulisan berita.

b. Jangan terlalu panjang - cukup satu lembar.

c. Langsung ke masalahnya dengan segera.

d. Penuhi unsur berita $5 \mathrm{~W}+1 \mathrm{H}$.

e. Berikan lebih dari satu nomor kontak -nomor telpon kantor, kontak pribadi, HP, e-mail, dan fax.

f. Jika memungkinkan, buatlah usulan mengenai orang-orang yang dapat diwawancara.

g. Cek/konfirmasi siaran pers yang sudah dikirimkan melalui fax, surat, atau email.

h. Jika perlu, seratakan ilustrasi foto, tabel, atau grafik atau bahan pendukung lainnya -makalah, naskah pidato, susunan acara, dsb.

i. Tuliskan pada kertas berkop-surat sehingga benar-benar resmi.

j. Tandatangani oleh pejabat paling berwenang, misalnya manajer humas, ketua panitia, dan/atau ketua lembaga/perusahaan.

k. Jika bersifat individu, misalnya artis, pakar, pejabat, ataupun warga biasa, sertakan fotokopi identitas. 


\section{Surat Pembaca}

Surat Pembaca (letter to the editor) mirip siaran pers, terutama dalam hal teknis penulisan dan pengiriman. Yang membedakan adalah dalam hal isi dan tujuannya. Isi dan tujuan surat pembaca biasanya merupakan tanggapan, sanggahan, klarifikasi, atau penggunaan Hak Jawab dan Hak Koreksi atas informasi yang dinilai salah dan merugikan. Surat pembaca berupa tanggapan, biasanya diawali dengan mengutip berita atau surat pembaca yang sebelumnya sudah dimuat, sehingga pembaca dapat mengetahui latar belakang masalah yang diklarifikasi.

3. Advertorial (adv)

Advertorial $=$ advertising dan editorial. Gabungan antara promosi dan opini atau pemberitaan tentang hal yang dipromosikan -produk, jasa, perusahaan, organisasi, aktivitas, atau program pemerintah. Bentuk tulisannya bisa berupa berita, feature, atau artikel. Advertorial sering disebut iklan dalam bentuk pemberitaan atau tulisan panjang.

Jenis advertorial a.1. adv produk, adv jasa, adv perusahaan, dan adv pemerintahan. Sifatnya bisa informatif, eksplanatif, interpretatif, persuasif, argumentatif, dan eksploratif.

\section{Brosur}

Brosur (Brochure) adalah selebaran cetakan satu halaman kertas yang terlipat dua atau lebih, berisi keterangan, informasi, atau gambaran tentang sebuah perusahaan, instansi, produk, atau jasa, atau bisa juga berisi sebuah ide dan kegiatan.

Jenis selebaran promosi sejenis brosur adalah booklet, yakni buku kecil tanpa jilid/cover berisi informasi dan gambar tentang suatu produk atau jasa. Bisa juga terdiri dari beberapa lembar kertas sehingga menyerupai buku. Penyebarannya sama dengan brosur, yakni dibagi-bagikan langsung kepada publik.

Sarana promosi mirip brosur adalah flyer, pamflet, leaflet, atau poster, yakni lembaran utuh tanpa lipatan/tidak terlipat. Pamflet (ukuran satu halaman kertas print), leaflet (ukuran kertas kecil), dan poster (“surat tempelan”, ukuran kertas besar) disebarkan dengan cara ditempel. Flyer biasanya digantung.

Ada juga yang disebut folder. Bentuknya mirip map, namun berisi banyak informasi dan bagian dalamnya terdapat kantung untuk menyimpan aneka berkas seperti surat, brosur, leaflet, kartu nama, dan sebagainya. Folder dapat berfungsi sebagai tempat penyimpan berkas informasi atau promosi.

\section{Press Conference/Media Kit}


Konferensi Pers (Press Conference) - undang media untuk menyampaikan informasi, dilakukan tidak rutin, insidental sesuai acara yang digelar, baik sebelum maupun sesudah kegiatan. Media Kit adalah bahan tertulis sehingga kalangan pers memiliki data akurat dan lengkap sebagai bahan berita. Bahan tertulis ini bisa berupa siaran pers, susunan acara, makalah, artikel, feature, bosur, proposal, atau informasi lengkap tentang kegiatan tujuan, jadwal, target, kepanitiaan, daftar pengisi acara, dsb.- dan dimasukkan dalam sebuah map atau amplop besar.

6. Naskah Pidato

Naskah pidato biasanya dilakukan penulis khusus yang disebut scriptwriter. Namun, ada punya petugas humas yang ditugaskan menulisnya. Naskah pidato terdiri dari bagian pembukaan, isi, dan penutup. Ditulis dengan gaya bahasa tutur (spoken words) atau gaya bahasa percakapan (conversational language) karena naskah itu untuk diucapkan, dibacakan, atau disuarakan.

\section{Newsletter}

Newsletter secara harfiyah artinya "laporan berkala" atau "surat berita". Merupakan media informasi dan komunikasi internal sebuah lembaga, biasanya terdiri dari dua hingga delapan lembar kertas kwarto atau folio, tanpa cover seperti majalah atau buku. Isinya bervariasi mirip majalah, misalnya agenda dan berita kegiatan, artikel, feature, gambar, dsb.

\section{In House Magazine}

In House Magazine atau Company Magazines adalah majalah internal sebuah lembaga/perusahaan. Desain atau tampilan dan rubrikasinya seperti majalah umum/komersil, namun isinya tentang informasi seputar "dapur" lembaga. Mengelola In House Magazine, juga Newsletter, sama dengan proses manajemen media massa pada umumnya, yakni melalui proses redaksional dan membutuhkan keterampilan meliput dan menulis berita layaknya wartawan.

Proses redaksional dimaksud adalah tahapan perencanaan (planing) - penentuan visi, misi, logo, moto, rubrikasi, editorial policy, dan style book; pengorganisasian (organizing) -penetapan susunan organisasi redaksi (pemred hingga reporter dan layouter); pelaksanaan (acting) -aktivitas jurnalistik seperti perencanaan liputan (rencana isi), peliputan, penulisan, editing, dan desain grafis, dan pengawasan (controling) -pengawasan dan evaluasi proses dan hasil kerja yang sudah dilaksanakan. 
Pelatihan ini menekankan pada makna belajar (learning). Menurut Crow \& Crow, belajar adalah proses perubahan perilaku atau pribadi seseorang berdasarkan praktek atau pengalaman tertentu. Artinya setelah memiliki pengalaman mengikuti pelatihan Public Speaking dan Dasar Penulisan Humas pada siswa-siswi SMA Muhammadiyah 3 Jakarta, diharapkan para peserta mendapat tambahan pengetahuan dan pengalaman yang dapat menunjang kegiatan dan kemampuannya dalam berorganisasi di sebuah lembaga.

Oleh sebab itu, pelatihan ini merupakan penyuluhan dan bertujuan untuk meningkatkan komunikasi menjadi seorang PR/ Humas yang cakap dalam melakukan komunikasi secara lisan dan tulisan. Sangat perlu untuk menjelaskan teknik komunikasi lisan dan tulisan dengan baik, dan diikuti dengan kegiatan simulasi dan praktek mengenai bentuk-bentuk komunikasi secara lisan dan tulisan yang harus dikuasai, sehingga diharapkan pada saat kegiatan penyuluhan telah selesai, seluruh peserta sudah memiliki keterampilan berkomunikasi secara lisan dan tulisan di dalam menunjang pekerjaannya sebagai seorang PR/Humas yang sesuai kebutuhan serta melakukan perbaikan kemampuan komunikasi secara berkesinambungan baik terutama bagi dirinya pribadi dan di lingkungan lembaga tempatnya bekerja.

1. Realialisasi Pemecahan Masalah

Pelatihan ini diharapkan dapat berguna bagi berbagai pihak, adapun pihak-pihak terkait yang diharapkan dapat berperan serta memperoleh manfaat dari pelatihan ini, adalah:

2. Bagi para siswa SMA Muhammadiyah 3 Jakarta

a. Peranan : sebagai peserta aktif yang menerima dan mentransfer pengetahuan dan skill yang diterimanya melalui pelatihan/penyuluhan ini

b. Manfaat : mampu melaksanakan komunikasi secara lisan dan tulisan pada lembaga tempatnya belajar dengan baik khususnya dalam kemampuan public speaking dan dasar penulisan humas.

\section{Bagi UHAMKA}

a. Peranan: sebagai agent of change. sehingga tidak ada staf Humas yang belum memiliki pengetahuan tentangkomunikasi lisan dan tulisan khususnya di lembaga tempatnya bertugas dan pengetahuan tentang public speaking dan menulis press release, sekaligus sebagai channel of information bagi penyebaran ilmu dan pengetahuan pada masyarakat luas. 
b. Manfaat : mampu berperan dalam pembangunan sosial kemasyarakatan sekaligus mengamalkan Tri Dharma Perguruan Tinggi.

3. Metode Yang Di gunakan

Proses pembelajaran membutuhkan metode pengajaran tertentu dari instruktur. Metode pengajaran dapat berbentuk ceramah, demonstrasi, diskusi, simulasi, role play serta praktek yang bertujuan untuk memberikan pemahaman pengetahuan, pemahaman aplikasi dan pemahaman analisis, sintesis serta evaluasi (Syah, 2002 : 202).

Untuk itu pada pelatihan penulisan Jurnalistik dan Dasar Penulisan Humas ini akan menggunakan metode pendidikan orang dewasa melalui ceramah dan simulasi, permainan peran dan praktek.

\section{Realisasi Pelaksanaan Kegiatan}

Hasil Pelaksanaan Pelatihan ini telah menunjukkan perubahan positif pada peserta yaitu pada siswa-siswi SMA Muhammadiyah 3 Jakarta, dalam hal pemahaman mengenai segala bentuk mengenai penulisan jurnalistik dan penulisan naskah Humas.

a. Kemampuan Penulisan Jurnalistik dan Naskah Humas

Para peserta memahami pentingnya tentang penulisan jurnalistik dan naskah kehumasan, dimana kemampuan ini sangat diperlukan untuk menunjang kemampuan berkomunikasi pada sebuah organisasi. Dengan mendapatkan informasi secara tepat tentang segala hal yang berkaitan dengan public speaking dan dasar penulisan humas diharapkan dapat meningkatkan kemampuan dalam berkomunikasi secara lisan dan tulisan dalam suatu organisasi.

Di Indonesia, masyarakat cenderung menghargai dan menerima seseorang yang mampu menyampaikan ide-idenya dalam bahasa yang dimengerti oleh publik. Hal ini membuktikan bahwa kemampuan komunikasi, menjadi kemampuan yang mutlak harus dimiliki setiap individu agar mampu bersaing di zaman yang semakin dinamis.

Praktisi PR berperan sebagai teknisi komunikasi untuk organisasinya. Seorang humas diharuskan memahami keahlian komunikasi dan jurnalistik karena ia akan ditugaskan untuk menulis news release, mengembangkan isi web, menangani kontak media, dan juga berhubungan dengan banyak publik di instansinya.

Selain itu, praktisi PR juga berperan sebagai fasilitator komunikasi. Peran seorang praktisi di sini adalah sebagai pendengar yang peka dan sebagai perantara komunikasi. Fasiltator bekerja sebagai penghubung antara organisasi dengan publiknya. Komunikasi 
akan selalu dijaga supaya berjalan dua arah dan memfasilitasi komunikasi tersebut dengan menyingkirkan segala rintangan sambil terus membuka jalur komunikasi. Tujuannya adalah memberi informasi yang dibutuhkan baik oleh instansi, dalam hal ini manajemen, maupun publiknya untuk membuat suatu keputusan atau pandangan demi kepentingan bersama.

Kegiatan Public Relations atau Humas pada hakikatnya merupakan bagian dari teknik kegiatan berkomunikasi (technique of communication) dengan ciri khas komunikasi dua arah (two way traffic communication) antara lembaga atau organisasi yang diwakilinya dengan publik atau sebaliknya.

Komunikasi dua arah yang efektif harus dipandang sebagai satu-satunya alat manajemen oleh PR yang dimanfaatkan dalam mengembangkan organisasi. Bagi PR, umpan balik lewat opini publik yang diciptakan akan membawa perbaikan, perubahan, perkembangan sebagai efeknya. Umpan balik atau feedback akan dianalisa oleh praktisi PR untuk menilai pendapat khalayak terhadap komunikasi yang telah PR lakukan. PR menganalisa apakah respon yang didapat positif sehingga berdampak baik terhadap citra atau malah negatif sehingga kurang menguntungkan posisi organisasi di mata masyarakat.

Salah satu tugas dari seorang PR (public relations) adalah menjalin hubungan baik dengan orang lain. Seringkali, seorang praktisi PR menghadapi suatu permasalahan yang berkaitan dengan orang lain dan menangani hubungan yang sensitif. Hubungan antara perusahaan dengan publiknya terjadi karena keduanya memiliki kepentingan yang saling terkait.

Terkadang masalah timbul pada hubungan antara perusahaan dengan publiknya. Praktisi PR layaknya memiliki kemampuan komunikasi yang baik dan mampu menjadi pihak yang netral ketika sebuah permasalahan itu terjadi. Kemampuan komunikasi ini harus dikembangkan terus menerus, karena apabila komunikasi itu dilaksanakan secara efektif dan produktif artinya akan membentuk pribadi yang semakin matang, dewasa, dan akan membentuk citra yang positif di hadapan orang lain. Namun, apabila kita tidak memiliki kemampuan atau berpotensi untuk berkomunikasi, akan muncul atau terjadi kemacetan dalam komunikasi.

Publik perlu diperhatikan, karena kegiatan public relations selain dijalankan untuk memperhatikan kepentingan organisasi juga harus memperhatikan kepentingan khalayak. Organisasi yang mampu mengintegrasikan dan memadukan keinginan dan 
kebutuhan informasi publiknya akan mampu berkembang dan mendapatkan manfaat untuk kemajuan instansinya, karena setiap publik yang terkait selalu diberitahu tentang kemajuan dan pencapaian organisasi. Dengan kata lain, publik akan merasa diberikan perhatian penuh dan diakui kontribusinya dalam organisasi.

Berdasarkan hasil evaluasi, siswa-siswi SMA Muhammadiyah 3 Jakarta mulai memahami segala hal mengenai public speaking dan dasar penulisan humas. Ini terbukti dari antusiasme yang besar dari para peserta.

b. Mengedukasi Kemampuan Penulisan Jurnalistik dan Naskah Humas

Tim memberikan pemahaman kepada para peserta mengenai berbagai istilah dalam public speaking dan dasar penulisan humas sebagai suatu kemampuan dasar yang harus dimiliki oleh seorang PR/Humas.

Hanya sebagian kecil dari manajer perusahaan, tokoh organisasi dan tokoh publik yang memiliki kemampuan menulis sama bagusnya dengan kemampuan berbicara. Kemampuan menulis dipakai untuk menulis artikel di media, pidato, memberikan pernyataan (testimoni) dan memo. Jika tidak di kelola dengan baik, bisa berdampak buruk bagi pencitraan perusahaan, organisasi atau tokoh tersebut. Untuk mengatasi hal ini, mereka seringkali membutuhkan penasehat dari seorang praktisi public relations. Nara sumber berbagi tulisan tentang bagaimana strategi kemampuan menulis seorang public relations atau jurnalis.

Public Relations harus memahami dulu faktor yang mempengaruhi pemahaman publik atas informasi yang dibaca, kemudian komunikasikan ide atau penjelasan kepada publik melalui tulisan yang jelas, enak dibaca dan mudah dipahami.

Pada prinsipnya ada beberapa hal krusial dalam penulisan naskah Public Relations yang perlu dipertimbangkan (Prayudi, 2007), supaya tercipta pemahaman yang baik dibenak publik terhadap organisasi, tokoh, atau perusahaan.

\section{Tujuan Penulisan}

Secara umum tujuan penulisan naskah PR sama dengan tujuan public relations. Grunig dan Hunt (1983:134) (Grunig, James E \& Todd Hunt. Managing Public Relations. Florida: Holt, Rinehart, and Winston Inc.) mengidentifikasi 5 tujan aktivitas PR, yakni : komunikasi, menerima pesan, penerimaan kognisi, pembentukan atau perubahan sikap (penilaian atau keinginan perilaku) dan perilaku terbuka. 
Kejujuran, fakta dan informasi yang disampaikan harus bisa memenuhi harapan dari berbagai publik organisasi, dan disaat yang bersamaan bisa menciptakan pengertian bersama antara organisasi dengan publik. Praktisi PR harus menjaga reputasi perusahaan di satu sisi dan memahami keinginan publik di sisi lain.

6. Objektivitas

Penulisan naskah harus mengacu kepada manfaatnya, serta terpisah dari identitas penulis. Agar informasi anonimus itu diterima publik, kata dan kalimat yang termuat harus memiliki integritas dan wewenang.

Integritas dipahami sebagai tulisan yang memuat kepentingan atau tujuan dari dikeluarkannya tulisan, sedangkan wewenang dipahami sebagai kompetensi atas dikeluarkannya tulisan yang dianggap dapat mewakili pihak manajemen.

7. Review Sumber Informasi

Praktisi PR harus teliti mengecek kembali naskahnya sebelum di publikasi. Mulai dari apakah gagasan pokok telah dituangkan dalam bahasa yang benar, sampai pengenalan karakater media tempat naskah akan diterbitkan.

Selain itu, dibutuhkan kutipan penjelasan dari tenaga ahli apabila menyangkut isu yang sangat bersifat teknis dan menyangkut nyawa manusia. Seperti: kandungan kimia, alat kesehatan, zat makanan dan lain sebagainya. Pastikan kata - kata istilah yang digunakan sudah dipahami secara jelas dan komprehensif.

8. Dampak yang diharapkan.

Selain dampak tulisan kepada publik yang membaca, seorang Public Relations juga perlu memikirkan dampaknya bagi media. Harus memberikan strategi solusi kreatif, bagaimana pihak media tersebut bisa mendapatkan persepsi positif yang mendalam.

Kemas informasi, pesan dan data mengenai perusahaan/organisasi dalam berbagai bentuk, seperti press kit atau media kit yang berisi factsheet, backgrounders yang pada prinsipnya memuat profil perusahaan, whitepaper, brosur, dan flier.

\section{Teknik Tulisan}

Teknik penulisan naskah harus sesuai dengan publik sasaran, misalnya pilihan kata, penggunaan tata bahasa, dan sisi yang ingin ditonjolkan dari naskah yang akan ditulis. Praktisi PR tidak menjual produk, tetapi membangun image produk dengan teknik edukasi konsumen. PR tidak menegaskan perusahaan telah mengeluarkan produk, tapi lebih dari memfokuskan pada manfaat dan keunggulan produk tersebut bagi konsumen. 
Penekanan terhadap kemampuan menulis bagi praktisi PR ini juga dipaparkan oleh Fraser P Seitel dalam bukunya The Practice of Public Relations (1984). Fraser P Seitel menekanan bahwa sangat penting para praktisi PR menguasai keterampilan menulis menulis sebagai kemampuan aplikasi praktis selain kemampuan konseling dan penilaian manajerial. Lebih jauh Seitel menegaskan bahwa, jika seorang tidak bias menulismengekspresikan ide di atas kertas - maka peluang sukses bagi seorang tersebut sangat kecil. Seitel juga menegaskan bahwa menulisbagi mata berbeda denganmenulis bagi telinga. Artinya menulis artikel untuk media massa atau majalah atau newsletter memiliki konsep dan bentuk yang berbeda dengan menulis teks (scripts) untuk dibaca dan didengarkan oleh publik.

Dengan demikian dalam hal penguasaan atau pemahaan teknik dalam penulisan berbagai naskah PR menjadi sangat penting sekali. Ada berbagai bentuk pelatihan penulisan naskah PR, juga ada beragam cara untk dapat menulis dengan baik guna mendukung fungsi PR secara aplikatif. Oleh karenanya pemahaman akan beberapa faktor penting yang biasa dijadikan pertimbangan dalam penulisan menjadi langkah yang penting. Faktor-faktor tersebut seperti bagaimana orang-orang bisa membaca informasi yang kita tulis, menilai baik buruknya informasi yang dibaca, dan pada akhirnya mengambil tindakan sesuai dengan harapan kita. Keahlian menulis mencakup bagaimana seseorang memiliki pemahaman mengenai apa yang akan ditlis, bagaimana pesan tersebut ditulis, dan melalui media apa termasuk bagaimana memahami teknik penulisan dan sosiologi media sekaligus.

Seperti juga dalam upaya menjalin hubungan baik dengan media, dalam penulisan, seorang PR juga harus memahami mediascape (jenis/bentuk media dengan berbagai karakteristiknya masing-masing) serta berbagai aspek lainnya yang dapat mendukung seorang PR menulis naskah dengan baik. Aspek-aspek krusial dalam penulisan naskah PR yang perlu juga dipahami adalah apa tujuan dari penulisan ini, objectivitas penulisan, konfirmasi ulang pada sumber dan fakta dari informasi yang ada, pemahaman akan dampak dari tulisan tersebut, serta teknik dasar penulisan termasuk di dalamnya adalah pemahaman akan perbedaan penulisan yang dilakukan oleh PR dengan Jurnalistik (media). Selain itu kemampuan menciptakan sebuah nilai berita dengan tetap berdasarkan fakta dan jujur juga menjadi pedoman utama penulisan naskah PR. Lebih jauh, seorang PR juga dituntut memahami ragam bentuk informasi yang memiliki nilai berita atau dapat dijadikan 
berita yang layak, seperti kebaruan informasi (timeliness), peristiwa yang dekat dengan keseharian (proximity), beberapa peristiwa yang layak diinformasikan semata-mata karena ada orang terkenal di dalamnya (eminence \& prominence), peristiwa yang memiliki dampak dan mempengaruhi aktivitas keseharian masyarakat (consequence\& impact), serta peristiwa yang menarik seputar kehidupan manusia (human interest).

Ada beragam aktivitas penulisan dalam PR yang juga perlu dipahami, seperti penulisan press release, feature, backgrounders, factsheet, whitepaper, dan brosur, penulisan untuk web organisasi, newsletter, laporan tahunan dan lainnya. Beberapa bentuk penulisan naskah PR ini juga telah dijelaskan secara singkat dalam tulisan sebelumnya (Media Relations: Media Relations: "Jangan hanya dijadikan "pemadam kebakaran" saja tapi sebagai teamwork dan keluarga anda), tetapi perlu dipahami bahwasannya penulisan press release akan berbeda dengan penulisan untuk feature atau lainnya. Dalam sistem penulisan jurnalistik dikenal konsep piramida terbalik yang juga bisa dijadikan acuan untuk beberapa penulisan naskah PR seperti penulisan press release, newsletter maupun feature dan lainnya. Dalam konsep Piramida Terbalik tentu anda sudah sangat sering melihat bentuknya atau bahkan mencoba untuk menulis dengan acuan konsep ini.

Dalam Piramida Terbalik teknik penulisan dipetakan menjadi tiga bagian menurun. Pertama adalah membuat lead, kemudian Body Text, dan bagian terakhir adalah penutup. Sesuai dengan urutan dalam Piramida Terbalik ini, Lead merupakan bagian paling penting dan didalamnya mengandung unsur 5W1H /W5H1 (Who, What, Where, When, Why dan How) dari sebuah peristiwa/momen yang terjadi. Untuk penulisan naskah berita, jurnalis senantiasa berusaha memenuhi enam unsure ini dalam pembuatan lead. Kemudian Body Text, atau latar belakang ini berisi bebagai informasi yang mampu memperjelas atau mendukung cerita atau berita pada lead atau penjabaran lead dengan dukungan fakta dan data yang lebih teknis. Untuk membuat tulisan itu lebih memiliki nilai, setelah memaparkan secara panjang lebar ide dan gagasan yang ada dalam lead dengan format menurun mulai dari fakta penting hingga yang kurang penting dalam body text, kini saatnya memasukkan sebuah kutipan.

Kutipan sangat bermanfaat selain untuk memberi kesempatan kepada orang yang diberitakan untuk berkomunikasi secara langsung dengan pembaca, juga oleh media dijadikan sebagai inisial narasumber. Kutipan ini juga bisa dijadikan sebagai transisi untuk mengarahkan pembaca dari satu paragraph ke paragraph berikutnya secara halus. 
Kemudian untuk naskah press release, jangan lupa cantumkan contact person. Hal ini untuk memudahkan wartawan / media untuk melakukan konfirmasi ulang atau sekedar untuk mencari tambahan informasi.

Pemaparan di atas memang masih sangat kurang untuk menambah penguasaa teknik seorang PR dalam menulis naskah PR. Dan untuk dapat menguasai teknik dan taktik menulis dengan baik bagi seorang PR diperlukan sebuah pelatihan yang khusus dan mengkhususkan pada penulisan naskah PR. Namun demikian pemahaman akan aspekaspek dalam penulisan seperti diuraikan di atas menjadi hal yang sangat krusial pagi seorang PR. Dan yang terpenting, dalam penulisan naskah, para praktisi (seorang PR) harus mampu menjembatani kepentingan pihak manajemen organisasi dengan kepentingan publik organisasi. Jadi menulis itu mudah karena sadar atau tidak setiap hari dalam aktivitas kita senantiasa bersentuhan dengan tulis-menulis. Namu demikian, menulis yang bisa mempengaruhi minat orang lain itu perlu dipelajari dengan seksama dan serius.

Setelah selesai ditampilkan beberapa contoh cara menulis peserta selanjutnya diberikan kesempatan untuk praktek menulis jurnalistik dan naskah humas. Selain itu peserta diberikan kesempatan untuk bertanya dan berdiskusi mengenai pengalaman, hambatan dan kesulitan dalam melakukan kemampuan komunikasi lisan dan tulisan.

Hasilnya peserta tampak bersemangat dan merasa senang karena mereka memperoleh pengetahuan dan informasi mengenai bentuk komunikasi secara tulisan yang dapat dipraktekan sehari-hari, maupun dalam komunikasi organisasi agar dapat meningkatkan kemampuan menulis.

10. Rancangan Evaluasi dan Indikator Pelaksanaan

Adapun rancangan evaluasi dan indikator pelaksanaan kegiatan pelatihan ini adalah sebagai berikut :

a. Rancangan Evaluasi :

Evaluasi pasca kegiatan rencananya akan dilaksanakan setiap bulan selama 4 bulan berturut-turut dengan jadwal sebagai berikut :

- Bulan kesatu : Peninjauan ke lokasi sebagai tahap awal untuk mengetahui pemahaman siswa mengenai kemampuan penulisan jurnalistik dan naskah humas 
- Bulan kedua : Peninjauan lokasi dan wawancara pada khalayak sasaran mengenai kemampuan penulisan jurnalistik dan naskah humas

- Bulan ke tiga : Peninjauan lokasi dan wawancara serta penerapan materi pelatihan peningkatan penulisan jurnalistik dan naskah humas bagi khlayak sasaran

- Bulan keempat : Peninjauan ke lokasi dan peningkatan kualitas pemahaman siswa mengenai segala bentuk penulisan jurnalistik dan naskah humas.

b. Indikator Pencapaian Tujuan

Yang menjadi indikator pencapaian tujuan dari kegiatan ini adalah :

- Secara Kuantitatif, berkurangnya angka siswa-siswi SMA Muhammadiyah 3 Jakarta yang tidak bisa berbicara/tampil di depan public dan menulis dasar-dasar penulisan

- Secara Kualitatif meningkatnya pemahaman siswa-siswi SMA Muhammadiyah 3 Jakarta mengenai public speaking dan dasar penulisan humas

Secara Kualitatif meningkatnya pengetahuan siswa-siswi SMA Muhammadiyah 3 Jakarta terhadap teknik public speaking dan dasar penulisan humas dan memahami cara melakukan komunikasi lisan dan komunikasi lisan dengan baik

\section{KESIMPULAN}

1. Upaya yang senantiasa diperjuangkan oleh seorang Jurnalis dan praktisi Public Relations adalah bagaimana dapat menginformasikan berbagai momen penting, khususnya yang berhubungan dengan terobosan dan perkembangan kekinian.

2. Pengabdian pada Masyarakat bagi Universitas Muhammadiyah Prof.Dr. HAMKA (UHAMKA) sebagai lembaga pendidikan tinggi merupakan wujud kepedulian lembaga ini pada masyarakat khususnya pada siswa-siswi SMA Muhammadiyah 3 Jakarta, dan umumnya pada dunia pendidikan. Kontribusi yang diberikan terpenting adalah bagaimana para siswa ini mendapat pelatihan dasar mengenai cara berkomunikasi secara lisan dan tulisan yang menjadi kemampuan dasar yang harus di miliki untuk dapat terjun di masyarakat.

\section{UCAPAN TERIMA KASIH}

Ucapan terima kasih kepada LPPM UHAMKA sebagai penyandang dana kegiatan ini. Terimakasih juga kepada SMA Muhammadiyah 3 Jakarta selaku mitra kegiatan. 


\section{DAFTAR PUSTAKA}

Abdulah, Aceng.2000. Kiat Berhubungan dengan Media Massa. Bandung: Remaja Rosdakarya

Bandura, Albert. 1977. Social Learning Theory. New Jersey: Prentice-Hall.

Gerungan, W. A. 1991. Psikologi Sosial. Bandung: Eresco.

Iriantara, Yosal dan A. Yani Surachman. 2006. Public Relation Writing: Pendekatan Teoritis dan ptaktis. Bandung. Simbiosa Rekatama Media

McCarty, Andrew. 2007. Mengembangkan Kepribadian dengan Berpikir Positif. Terj. How to Positive Thinking. Jakarta: Prestasi Pustakakarya.

Rakhmat, Jalaluddin.1985. Psikologi Komunikasi. Bandung : Remadja Karya.

Rachmadi, F. 1994. Public Relations dalam Teori dan Praktek. Jakarta : Galamedia Pustaka Utama

Romli, Asep Syamsul. 2004. Jurnalistik Terapan: Panduan Kewartawanan dan Kepenulisan. Bandung : Baticpress

Sameto, Hudoro.1996. Kiat Sukses Mengolah Komunikasi. Jakarta: Puspa Sawara.

Soemirat, Soleh dan Elvinaro Ardianto. 2002. Dasar-dasar Public Relations. Bandung : Remaja Rosdakarya

Trenholm, Sarah. 1986.Human Communication Theory. New Jersey : Prentice Hall. 